\title{
Comments on controversial tick (Acari: Ixodida) species names and species described or resurrected from 2003 to 2008
}

\author{
Alberto A. Guglielmone ${ }^{1}$, Richard G. Robbins ${ }^{2}$, Dmitry A. Apanaskevich ${ }^{3}$, \\ Trevor N. Petney ${ }^{4}$, Agustín Estrada-Peña ${ }^{5}$ and Ivan G. Horak ${ }^{6}$
}

(1) Estación Experimental Agropecuaria Rafaela, Instituto Nacional de Tecnología Agropecuaria, C.C. 22, CP 2300 Rafaela, Santa Fe, Argentina

(2) DPMIAC/AFPMB, Walter Reed Army Medical Center, Washington, DC 20307-5001, USA

(3) U.S. National Tick Collection, Institute of Arthropodology and Parasitology, Georgia Southern University, Statesboro, Georgia 30460-8056, USA

(4) Abteilung für Ökologie und Parasitologie, Zoologisches Institut I, Kornblumenstrasse 13, 76131 Karlsruhe, Germany

(5) Facultad de Veterinaria, Universidad de Zaragoza, Miguel Servet 177, Zaragoza, CP 50013, Spain

(6) Department of Veterinary Tropical Diseases, Faculty of Veterinary Science, University of Pretoria, Onderstepoort, Pretoria, 0110, South Africa

Alberto A. Guglielmone (Corresponding author) ( aguglielmone@rafaela.inta.gov.ar)

Richard G. Robbins ( richard.robbins@osd.mil)

Trevor N. Petney ( Trevor.petney@t-online.de)

Agustín Estrada-Peña ( aestrada@unizar.es)

Ivan G. Horak ( ivan.horak@up.ac.za)

\begin{abstract}
There are numerous discrepancies in recent published lists of the ticks of the world. Here we review the controversial names, presenting evidence for or against their validity and excluding some altogether. We also address spelling errors and present a list of 17 species described or resurrected during the years 2003-2008. We consider the following 35 tick species names to be invalid: Argas fischeri Audouin, 1826, Ornithodoros boliviensis Kohls and Clifford, 1964, Ornithodoros steini (Schulze, 1935), Amblyomma acutangulatum Neumann, 1899, Amblyomma arianae Keirans and Garris, 1986, Amblyomma bibroni (Gervais, 1842), Amblyomma colasbelcouri (Santos Dias, 1958), Amblyomma concolor Neumann, 1899, Amblyomma cooperi Nuttall and Warburton, 1908, Amblyomma curruca Schulze, 1936, Amblyomma cyprium Neumann, 1899, Amblyomma decorosum (Koch, 1867), Amblyomma nocens Robinson, 1912, Amblyomma perpunctatum (Packard, 1869), Amblyomma striatum Koch, 1844, Amblyomma superbum Santos Dias, 1953, Amblyomma testudinis (Conil, 1877), Amblyomma trinitatis Turk, 1948, Dermacentor confractus (Schulze 1933), Dermacentor daghestanicus Olenev, 1928, Haemaphysalis himalaya Hoogstraal, 1966, Haemaphysalis vietnamensis Hoogstraal and Wilson, 1966, Hyalomma detritum Schulze, 1919, Ixodes apteridis Maskell, 1897, Ixodes donarthuri Santos Dias, 1980, Ixodes kempi Nuttall, 1913, Ixodes neotomae Cooley, 1944, Ixodes rangtangensis Teng, 1973, Ixodes robertsi Camicas, Hervy, Adam and Morel, 1998, Ixodes serrafreirei Amorim, Gazetta, Bossi and Linhares, 2003, Ixodes tertiarius Scudder, 1885, Ixodes uruguayensis Kohls and Clifford, 1967, Ixodes zealandicus Dumbleton, 1961, Ixodes zumpti Arthur, 1960 and Rhipicephalus camelopardalis Walker and Wiley, 1959. We consider the following 40 names valid: Argas delicatus Neumann, 1910, Argas vulgaris Filippova, 1961, Ornithodoros
\end{abstract}


aragaoi Fonseca, 1960, Ornithodoros dugesi Mazzoti, 1943, Ornithodoros knoxjonesi Jones and Clifford, 1972, Ornithodoros marocanus Velu, 1919, Ornithodoros nattereri Warburton, 1927, Amblyomma beaurepairei Vogelsang and Santos Dias, 1953, Amblyomma crassipes (Neumann, 1901), Amblyomma echidnae Roberts, 1953, Amblyomma fuscum Neumann, 1907, Amblyomma orlovi (Kolonin, 1995), Amblyomma parkeri Fonseca and Aragão, 1952, Amblyomma pseudoconcolor Aragão, 1908, Bothriocroton oudemansi (Neumann, 1910), Bothriocroton tachyglossi (Roberts, 1953), Dermacentor abaensis Teng, 1963, Dermacentor confragus (Schulze 1933), Dermacentor ushakovae Filippova and Panova, 1987, Haemaphysalis anomaloceraea Teng, 1984, Haemaphysalis filippovae Bolotin, 1979, Haemaphysalis pavlovskyi Pospelova-Shtrom, 1935, Hyalomma excavatum Koch, 1844, Hyalomma isaaci Sharif, 1928, Hyalomma rufipes Koch, 1844, Hyalomma turanicum Pomerantzev, 1946, Ixodes arabukiensis Arthur, 1959, Ixodes boliviensis Neumann, 1904, Ixodes columnae Takada and Fujita, 1992, Ixodes maslovi Emel'yanova and Kozlovskaya, 1967, Ixodes sachalinensis Filippova, 1971, Ixodes siamensis Kitaoka and Suzuki, 1983, Ixodes sigelos Keirans, Clifford and Corwin, 1976, Ixodes succineus Weidner, 1964, Rhipicephalus aurantiacus Neumann, 1907, Rhipicephalus cliffordi Morel, 1965, Rhipicephalus pilans Schulze, 1935, Rhipicephalus pseudolongus Santos Dias, 1953, Rhipicephalus serranoi Santos Dias, 1950 and Rhipicephalus tetracornus Kitaoka and Suzuki, 1983.

Keywords Ixodida - Argasidae - Ixodidae - Species names

\section{Introduction}

Over the last decade, there have been three attempts to construct complete lists of the world's tick species (Acari: Ixodida: Argasidae, Ixodidae and Nuttalliellidae): Camicas et al. (1998), Horak et al. (2002), and Barker and Murrell (2004). Recently, Nava et al. (2009) joined this endeavor, compiling a list of 879 species (186 in the Argasidae, 692 in the Ixodidae, and 1 in the Nuttalliellidae), commenting on what they consider mistakes in the list of Barker and Murrell (2004), and adding or deleting names based on the argasid list of Keirans (1992) and the ixodid list of Horak et al. (2002). As stated in its preface, the list of Horak et al. (2002) amounts to an exercise in consensus, involving some of the very scientists responsible for previous lists. The compilation by Barker and Murrell (2004) ostensibly sought to capture names that had been overlooked in the works of Keirans (1992), Camicas et al. (1998), Keirans and Robbins (1999), and Horak et al. (2002). However, Barker and Murrell (2004) also missed several names (e.g., Argas delicatus Neumann, 1910, Amblyomma concolor Neumann, 1899 and Ixodes robertsi Camicas, Hervy, Adam and Morel, 1998) that appear exclusively in Camicas et al. 1998. Clearly, there are numerous disagreements among these lists. Here we discuss all the controversial tick names that have come to our attention, correct a number of common spelling errors, and provide a list of species described or resurrected during the years 2003-2008.

There are several competing phylogenies of the Argasidae and the Ixodidae. Thus, Filippova (1966), Pospelova-Shtrom (1969), Hoogstraal (1985), Klompen and Oliver (1993), and Camicas et al. (1998) offer different arrangements of the genera and subgenera of the Argasidae, while Hoogstraal and Aeschlimann (1982), Black and Piesman (1994), Filippova (1994), Camicas et al. (1998), Barker and Murrell (2002) and Horak et al. (2002), among others, present classifications of the Ixodidae with varying degrees of congruence. The 
authors of the present paper themselves disagree on the systematic status of several genera, and for this reason we have been compelled to compromise, selecting - but not endorsing the argasid phylogeny of Hoogstraal (1985), which comprises the genera Antricola, Argas, Nothoaspis, Ornithodoros, and Otobius, and the ixodid listing of Horak et al. (2002), which recognizes the genera Amblyomma, Anomalohimalaya, Bothriocroton, Cosmiomma, Dermacentor, Haemaphysalis, Hyalomma, Ixodes, Margaropus, Nosomma, Rhipicentor, and Rhipicephalus. Additionally, we include the fossil genus Cornupalpatum. Our compilation focuses on species names, and is therefore largely free of phylogenetic argument, but where generic assignments differ from those in Hoogstraal (1985) or Horak et al. (2002), we have discussed them in order to underscore the current divergence of professional opinion. Ongoing research in molecular genetics promises further upheaval in the higher-level classification of ticks and other acarines.

\section{Controversial tick names considered invalid}

\section{Argasidae}

Argas fischeri Audouin, 1826 is listed as a valid species in Camicas et al. (1998) and in Barker and Murrell (2004) [where it is included in the genus Carios] but not in Horak et al. (2002). Hoogstraal (1958) and Filippova (1964) treated A. fischeri as a junior synonym of Argas vespertilionis Latreille, 1796. Both authors believe that $A$. fischeri may be a valid name, but its resurrection will hinge on comparison of African and European tick populations, and, to the best of our knowledge, such studies have not yet been conducted. We therefore consider $A$. fischeri invalid, at least provisionally.

Ornithodoros boliviensis Kohls and Clifford, 1964 is included in Camicas et al. (1998) [as Alectorobius boliviensis] and in Barker and Murrell (2004) but not in Horak et al. (2002). This name is preoccupied by O. boliviensis Bacherer Gutiérrez, 1931, a synonym of Otobius megnini (Dugès, 1883), and the species was accordingly renamed O. kohlsi Guglielmone and Keirans, 2002, as discussed in Guglielmone and Keirans (2002). Horak et al. (2002) included the new specific epithet under the name Carios kohlsi, while Barker and Murrell (2004) incorrectly listed both names (O. boliviensis and C. kohlsi).

Ornithodoros steini (Schulze, 1935) is included in Horak et al. (2002) and in Barker and Murrell (2004) but not in Camicas et al. (1998). This name is a junior synonym of $O$. batuensis Hirst, 1929, as discussed by Klompen et al. (1995), who consider this species to belong to the genus Carios, while Camicas et al. (1998) place it in the genus Alectorobius. The inclusion of O. steini in Horak et al. (2002) and in Barker and Murrell (2004) is surely an oversight because, according to the phylogeny used by these authors, this species should belong to the genus Carios. We agree with Klompen et al. (1995) and consider this name invalid.

\section{Ixodidae}

Amblyomma acutangulatum Neumann, 1899 does not appear in Horak et al. (2002) but is cited in Camicas et al. (1998) and in Barker and Murrell (2004). Robinson (1926) inspected the type specimen, which was in poor condition, in the Natural History Museum, London. It was not included in the list of that museum's types published by Keirans and Hillyard (2001) 
and has probably been lost, making comparison with other species impossible. The descriptions of the female (the only known stage) by Neumann (1899) and Robinson (1926) are not sufficient to confirm the validity of this species, the type of which is said to have been collected in one of the Fiji Islands. We conclude that A. acutangulatum is not a valid species.

Amblyomma arianae Keirans and Garris, 1986 is not included in Camicas et al. (1998) or Horak et al. (2002) but is listed in Barker and Murrell (2004). Amblyomma arianae is a junior synonym of Amblyomma quadricavum (Schulze, 1941), as discussed in Keirans and Klompen (1996). Barker and Murrell (2004) incorrectly listed both names.

Amblyomma bibroni (Gervais, 1842) is included in Camicas et al. (1998) and in Barker and Murrell (2004) but not in Horak et al. (2002). As discussed in Guglielmone et al. (2003), Santos Dias (1958), and Camicas et al. (1998) considered A. dissimile Koch, 1844 a synonym of A. bibroni-originally Ixodes bibronii-but no type comparison was attempted. Moreover, Estrada-Peña and Castellá (1994) stated that I. bibroni Gervais, 1842 is a name lacking a formal description. And while Gervais (1844) briefly summarized his new species, he confused the issue by stating that his specimens were collected in 1843 (page 249). This lack of clarity or any subsequent redescription of the type material has led us to doubt the validity of A. bibroni, at least for the time being. Barker and Murrell (2004) incorrectly listed both A. bibroni and A. dissimile.

Amblyomma colasbelcouri (Santos Dias, 1958) is listed as a valid name in Barker and Murrell (2004) but not in Camicas et al. (1998) or Horak et al. (2002). This name was originally applied to a species in the former genus Aponomma but was subsequently recognized to belong in Haemaphysalis (Petney and Keirans 1996). Therefore, the valid name for this tick is actually H. colasbelcouri (Santos Dias, 1958). Barker and Murrell (2004) incorrectly included both $A$. colasbelcouri and $H$. colasbelcouri as valid tick names.

Amblyomma concolor Neumann, 1899 is considered a valid species by Camicas et al. (1998) but not by Horak et al. (2002) or Barker and Murrell (2004). Keirans and Hillyard (2001) examined a syntype (female) and concluded that $A$. concolor is a junior synonym of $A$. auricularium (Conil, 1878).

Amblyomma cooperi Nuttall and Warburton, 1908 is included in Barker and Murrell (2004) but not in the other two lists. This name is a junior synonym of A. dubitatum Neumann, 1899, as discussed in Estrada-Peña et al. (2002), who examined the type (female). Barker and Murrell (2004) incorrectly included both these names in their list.

Amblyomma curruca Schulze, 1936 is included in Camicas et al. (1998) and Barker and Murrell (2004) [where it is spelled curraca] but not in Horak et al. (2002). However, examination of the type showed that this name is a junior synonym of A. auricularium (Conil, 1878) [Fairchild et al. 1966; D.M. Barros-Battesti, personal communication].

Amblyomma cyprium Neumann, 1899 is included in Barker and Murrell (2004) but not in Camicas et al. (1998) or Horak et al. (2002). Keirans, in Voltzit and Keirans (2002), determined that the types of A. cyprium and A. breviscutatum Neumann, 1899 are conspecific, and since $A$. breviscutatum has page priority over A. cyprium, the latter falls as a junior synonym (see also Santos Dias 1956). Barker and Murrell (2004) listed A.

breviscutatum and $A$. cyprium without justifying their position. 
Amblyomma decorosum (Koch, 1867) is included in Camicas et al. (1998) [as a member of the genus Aponomma] and Barker and Murrell (2004) but not in Horak et al. (2002). This name was reduced to a junior synonym of Bothriocroton undatum (Fabricius, 1775) by Klompen et al. (2002).

Amblyomma nocens Robinson, 1912 is not included in Horak et al. (2002) but appears in the lists of Camicas et al. (1998) and Barker and Murrell (2004). This name is a junior synonym of A. pomposum Dönitz, 1909, as determined by Keirans and Hillyard (2001), who examined a syntype (male).

Amblyomma perpunctatum (Packard, 1869) is included in Camicas et al. (1998) and Barker and Murrell (2004) but not in Horak et al. (2002). Camicas et al. (1998) agree with Santos Dias (1961) in considering A. geayi Neumann, 1899 a junior synonym of $A$. perpunctatum, but this view was not accepted by Fairchild et al. (1966), who claimed that Packard's (1869) description was inadequate. We provisionally agree with the last opinion, pending comparison of the types. In any event, there is currently no justification for Barker and Murrell's (2004) listing of both A. perpunctatum and A. geayi.

Amblyomma striatum Koch, 1844 is included in Barker and Murrell (2004) but not in Camicas et al. (1998) or Horak et al. (2002). This name is a junior synonym of A. aureolatum (Pallas, 1772), as discussed by Aragão and da Fonseca (1961b). Barker and Murrell (2004) incorrectly listed both $A$. aureolatum and $A$. striatum as valid names.

Amblyomma superbum Santos Dias, 1953 is treated as a valid name in Camicas et al. (1998) and in Barker and Murrell (2004) but not in Horak et al. (2002). Walker and Olwage (1987) consider this species a junior synonym of $A$. pomposum, a view that conflicts with Santos Dias (Walker and Olwage 1987) but is supported by Voltzit and Keirans (2003), who reduced this name to A. supurbum (n. syn.), a misspelling.

Amblyomma testudinis (Conil, 1877) is included in Barker and Murrell (2004) but not in Camicas et al. (1998) or Horak et al. (2002). This name is a junior synonym of A. argentinae Neumann, 1904, having been originally described as Ixodes testudinis Conil, 1877, a name preoccupied by I. testudinis Leydig, 1855, which is a synonym of Hyalomma aegyptium (Linnaeus, 1758), as discussed in Guglielmone et al. (2001). Barker and Murrell (2004) incorrectly listed both A. argentinae and A. testudinis.

Amblyomma trinitatis Turk, 1948 is included in Barker and Murrell (2004) [spelled as trinitatus] and Camicas et al. (1998) but not in Horak et al. (2002). This name is a junior synonym of A. dissimile, as determined by Keirans and Hillyard (2001).

Dermacentor confractus (Schulze 1933) is listed in Barker and Murrell (2004) and in Camicas et al. (1998) but not in Horak et al. (2002). Schulze (1933) described this species as Indocentor confractus Schulze 1933 and Indocentor confragus Schulze 1933 (vide infra), but later (Schulze 1935) maintained that the correct name was confragus. We reject the name confractus.

Dermacentor daghestanicus Olenev, 1928, is included in Barker and Murrell (2004) and in Camicas et al. (1998) but not in Horak et al. (2002). This name is a junior synonym of $D$. niveus Neumann, 1897, as noted by Filippova (1997). 
Haemaphysalis himalaya Hoogstraal, 1966 is treated as a valid species in Barker and Murrell (2004) but not in Horak et al. (2002). It is considered a junior synonym of $H$. sundrai Sharif, 1928 by Camicas et al. (1998), which accords with the opinion of Hoogstraal and Kim (1985).

Haemaphysalis vietnamensis Hoogstraal and Wilson, 1966, is listed as a valid species in Horak et al. (2002) and in Barker and Murrell (2004) but is considered a synonym of $H$. colasbelcouri (Santos Dias 1958) by Camicas et al. (1998). J. E. Keirans (personal communication to I. G. Horak) agrees with Camicas et al. (1998), and we have also concluded that $H$. vietnamensis is not a valid species.

Hyalomma detritum Schulze, 1919 is treated as a valid species in all three recent tick checklists, when, in actuality, this name is a junior synonym of $H$. scupense Schulze, 1919, a reversal of the checklist classifications (Filippova 2003). Filippova (2003) considers 1918 the year of publication of $H$. scupense, but in fact the description of this species was printed in 1919 (Hoogstraal 1956). Hyalomma scupense is an economically important tick species that is widely known in the West as $H$. detritum. Therefore, to avoid confusing workers who only use the name $H$. detritum, we propose writing " $H$. scupense $(=H$. detritum)" when referring to this tick species.

Ixodes apteridis Maskell, 1897 is listed as a valid taxon under the name Scaphixodes apteridis by Camicas et al. (1998), who treat I. anatis Chilton, 1904 as a junior synonym. Barker and Murrell (2004) list both I. anatis and I. apteridis as valid, but Horak et al. (2002) recognize only I. anatis. Dumbleton (1953) discussed this problem and noted that I. apteridis has priority. However, he concluded that $I$. anatis should be retained because the types of $I$. apteridis were lost and the species could not be determined from the published description. We consider I. apteridis a nomen nudum.

Ixodes donarthuri Santos Dias, 1980 is considered a valid taxon in Camicas et al. (1998) and in Barker and Murrell (2004) but not in Horak et al. (2002). Keirans and Hillyard (2001) examined a paratype of $I$. donarthuri and concluded that this name is a junior synonym of $I$. neitzi Clifford, Walker and Keirans, 1977.

Ixodes kempi Nuttall, 1913 is considered a valid taxon by Camicas et al. (1998) and Barker and Murrell (2004) but not by Horak et al. (2002). Keirans and Brewster (1981) examined the lectotype and paralectotypes and concluded that $I$. kempi is a junior synonym of I. granulatus Supino, 1897.

Ixodes neotomae Cooley, 1944 is considered a valid species in Camicas et al. (1998) and in Barker and Murrell (2004) but not in Horak et al. (2002). This name is a junior synonym of $I$. spinipalpis Hawden and Nuttall, 1916, as determined by Norris et al. (1997) after careful study.

Ixodes rangtangensis Teng, 1973 is listed as a junior synonym of I. moschiferi Nemenz, 1968 in Camicas et al. (1998) but is accorded species rank in Horak et al. (2002) and in Barker and Murrell (2004). Later, Teng (1986) concluded that I. rangtangensis is a synonym of $I$. moschiferi, and we accept this decision.

Ixodes robertsi Camicas, Hervy, Adam and Morel, 1998 is listed as a nomen novum in Camicas et al. (1998) but is ignored in Horak et al. (2002) and in Barker and Murrell (2004). 
Camicas et al. (1998) applied this name to I. cornuatus Roberts, 1960, which they considered preoccupied by I. cornuatus Olenev (1941). However, J. E. Keirans (personal communication to I. G. Horak) considers I. cornuatus Olenev a nomen nudum, thus validating the species described by Roberts (1960). Olenev (1941) provided no formal description of I. cornuatus (which he proposed as a new variety of I. persulcatus), and we therefore concur that there is no argument for the validity of $I$. robertsi.

Ixodes serrafreirei Amorim, Gazeta, Bossi and Linhares, 2003 was inadequately described (Amorim et al. 2003) and is thus a nomen nudum (Venzal et al. 2008b).

Ixodes tertiarius Scudder, 1885 is the name for a fossil tick species. It is not included in either Horak et al. (2002) or Barker and Murrell (2004); however, Camicas et al. (1998) listed this name under the heading "fossil taxa" without further elaboration. We were unable to examine the original description in "Scudder, S.H. 1885. A contribution to our knowledge of Paleozoic arachnids. Proc. Am. Acad. Sci. (ser. 2), 12" as described in Weidner (1964), but found this name, without formal description but accompanied by a figure, in Scudder (1885); there is also a brief description of I. tertiarius in Scudder (1890). The figure and description provide no help in determining the genus of this tick. We therefore consider I. tertarius a nomen nudum. It would be worthwhile to locate this fossil, whose study may shed light on tick evolution.

Ixodes uruguayensis Kohls and Clifford, 1967 is included in Camicas et al. (1998) and in Barker and Murrell (2004) but not in Horak et al. (2002). This name is a junior synonym of $I$. longiscutatus Boero, 1944, as discussed in Venzal et al. (2001), who demonstrated that the larvae and nymphs of $I$. uruguayensis (the only known stages of this tick) are in fact the immature stages of I. longiscutatus. Barker and Murrell (2004) incorrectly listed both names.

Ixodes zealandicus Dumbleton, 1961, is considered valid in Camicas et al. (1998) and in Barker and Murrell (2004) but is listed as a subspecies of I. auritulus Neumann, 1904 in Horak et al. (2002). All these authors erroneously cite 1953 as the year of description of zealandicus. Barros-Battesti et al. (2003) described a new species in the subgenus Multidentatus, to which I. auritulus belongs, and also treat the name zealandicus as a subspecies of I. auritulus. We provisionally agree.

Ixodes zumpti Arthur, 1960 is listed as a junior synonym of I. kerguelenensis André and Colas-Belcour, 1942 in Camicas et al. (1998) but as a full species in Horak et al. (2002) and in Barker and Murrell (2004). Arthur (1965) stated that the female of I. zumpti is similar to that of I. kerguelenensis, but convincing evidence of their synonym was provided by Wilson (1970), and we therefore consider I. zumpti to be an invalid species name.

Rhipicephalus camelopardalis Walker and Wiley, 1959 is considered a valid species in Camicas et al. (1998) but not in Horak et al. (2002) or Barker and Murrell (2004). Walker et al. (2000) examined the types of both species and determined that $R$. camelopardalis is a junior synonym of $R$. longicoxatus Neumann, 1905. 


\section{Controversial tick names considered valid}

\section{Argasidae}

Argas vulgaris Filippova, 1961 is listed as "?=Argas delicatus Neumann, 1910" in Camicas et al. (1998), Horak et al. (2002) and Barker and Murrell (2004). Camicas et al. (1998) also list Argas delicatus Neumann, 1910 as "cf.? Argas vulgaris Filippova, 1961." Both species appear to be closely related, but, unlike A. delicatus, the name A. vulgaris has been extensively used. Argas delicatus was included in the subgenus Argas by Kaiser et al. (1964). We have been unable to locate any type comparison in the literature and consider both names valid, pending further investigation.

Ornithodoros aragaoi Fonseca, 1960 is included as a valid species in the genus Carios in Horak et al. (2002) and Barker and Murrell (2004), while Camicas et al. (1998) consider it a probable junior synonym of $O$. rudis Karsch, 1880, which they regard as a member of the genus Alectorobius. Guglielmone et al. (2003) do not include this taxon in their list of Neotropical ticks. Darci M. Barros-Battesti (personal communication) examined the type material deposited in the Instituto Butantan (São Paulo, Brazil) but was unable to confirm the synonymy in Camicas et al. (1998). We consider O. aragaoi provisionally valid until type comparison demonstrates otherwise.

Ornithodoros dugesi Mazzoti, 1943 is generally considered a junior synonym of O. talaje (Guérin-Méneville, 1849), and is classified in the genus Alectorobius in Camicas et al. (1998) and Carios in Horak et al. (2002) and Barker and Murrell (2004). This view is not shared by Butler and Gibbs (1984). After studying larvae of the O. talaje species group, J.M. Venzal et al. (2008a) concluded that a new species is present within this group and that $O$. dugesi may be valid. We provisionally accept this conclusion.

Ornithodoros knoxjonesi Jones and Clifford, 1972 is thought to be a junior synonym of $O$. dyeri Cooley and Kohls, 1944, in Camicas et al. (1998) but these authors provide no evidence justifying their position. This species is considered valid in Horak et al. (2002) and in Barker and Murrell (2004). Jones and Clifford (1972) described differences in larval chaetotaxy and other morphological features. We therefore tentatively regard $O$. knoxjonesi as a valid name.

Ornithodoros marocanus Velu, 1919, is treated as a valid species in Horak et al. (2002) and in Barker and Murrell (2004) but as a junior synonym of O. erraticus (Lucas, 1849) in Camicas et al. (1998), who place this species in the genus Alectorobius. We have found no published type comparison between these taxa, and we therefore provisionally accept both as valid species.

Ornithodoros nattereri Warburton, 1927 is listed as a valid species in Horak et al. (2002) and in Barker and Murrell (2004) but is classified as a junior synonym of O. rostratus Aragão, 1911 in Camicas et al. (1998). However, Aragão and da Fonseca (1961a) were able to morphologically separate these species. We tentatively consider $O$. nattereri a valid name. 


\section{Ixodidae}

Amblyomma beaurepairei Vogelsang and Santos Dias, 1953 is included in Camicas et al. (1998) but not in Horak et al. (2002) and Barker and Murrell (2004). Guglielmone et al. (2003) treat this species as valid in their list of Neotropical ticks and consider A. beaurepairei to be close to A. inornatum (Banks, 1909) and A. auricularium (Conil, 1878). Jones et al. (1972) were unable to locate the types of this species, and Prof. Roy Meléndez (personal communication) recently reported another unsuccessful search for the types. The description of this species by Vogelsang and Santos Dias (1953) is adequate but in the absence of types we are considering $A$. beaurepairei tentatively valid.

Amblyomma crassipes (Neumann, 1901) [formerly Aponomma] is treated as a valid species in Horak et al. (2002) and in Barker and Murrell (2004) but is considered a junior synonym of Aponomma fuscolineatum (Lucas, 1847) in Camicas et al. (1998). Kaufman (1972) stated that both species are similar but preferred to maintain their separate status because so little material was available for examination and the types had not been compared.

Amblyomma echidnae Roberts, 1953 is listed as a valid species in Horak et al. (2002) and in Barker and Murrell (2004) but is classified as a junior synonym of A. australiense Neumann, 1905 in Camicas et al. (1998). Roberts (1970) refers to small differences between these taxa and leaves open the possibility that A. echidnae is a subspecies of A. australiense. We tentatively consider A. echidnae valid, pending clarification of its status.

Amblyomma fuscum Neumann, 1907 is considered valid in Camicas et al. (1998) and in Barker and Murrell (2004) but not in Horak et al. (2002). This taxon is included in the list of Neotropical ticks by Guglielmone et al. (2003), and Barros-Battesti et al. (2005) clearly demonstrated its validity.

Amblyomma orlovi (Kolonin, 1995) is considered a valid species by Camicas et al. (1998) [under the genus Aponomma], Horak et al. (2002) and Barker and Murrell (2004). It was originally described from Vietnam (Kolonin 1995), but later Kolonin (2003) concluded that his specimens of $A$. orlovi had originated in tropical West Africa. While we tentatively consider A. orlovi a valid name, our reading of the original description strongly suggests that this species is a junior synonym of $A$. transversale (Lucas, 1844).

Amblyomma parkeri Fonseca and Aragão, 1952 is considered valid in Camicas et al. (1998) and in Barker and Murrell (2004) but not in Horak et al. (2002). Guglielmone et al. (2003) included it in their list of Neotropical tick taxa, and its status has since been validated by morphological and molecular studies that will be published soon (Marcelo B. Labruna, personal communication).

Amblyomma pseudoconcolor Aragão, 1908 is listed as a valid species in Horak et al. (2002) and in Barker and Murrell (2004) but is consigned to the synonymy of A. auricularium (Conil, 1878) in Camicas et al. (1998). While it is true that males of both species are sometimes difficult to differentiate because the scutal ornamentation (a crucial diagnostic character) is often indistinct in A. pseudoconcolor (Jones et al., 1972), females can easily be separated. Moreover, 16S rDNA sequences show differences between the two taxa (Nava et al., 2008). 
Bothriocroton oudemansi (Neumann, 1910) is listed as a valid species in Horak et al. (2002) and in Barker and Murrell (2004). Camicas et al. (1998) followed Kaufman (1972) in considering this name a junior synonym of Bothriocroton concolor (Neumann, 1899) (originally Aponomma concolor) but Beati et al. (2008) presented convincing evidence for the validity of $B$. oudemansi.

Bothriocroton tachyglossi (Roberts, 1953) [n. syn.] is considered a synonym of Bothriocroton hydrosauri (Denny, 1843) by Camicas et al. (1998) [under the genus Aponomma], but Andrews et al. (2006) soundly resurrected the species, again as an Aponomma.

Dermacentor abaensis Teng, 1963 is considered valid in Camicas et al. (1998), Horak et al. (2002) and Barker and Murrell (2004). However, Hoogstraal (footnote in English translation of Teng 1963) considered this species to be D. everestianus Hirst, 1926. Robbins and Robbins (2003) also treat $D$. abaensis as a junior synonym of $D$. everestianus, but because no definitive study supports this synonymy, we are tentatively accepting $D$. abaensis as valid.

Dermacentor confragus (Schulze 1933), originally described as Indocentor confragus Schulze 1933, and concurrently as Indocentor confractus Schulze 1933 (vide supra), was until recently a "lost" taxon. However, one of us (TNP) has located the types of this species in the Zoological Museum, Berlin, Germany. Pending studies of this material, we are considering $D$. confragus valid.

Dermacentor ushakovae Filippova and Panova, 1987 is listed as a valid species in Horak et al. (2002) and in Barker and Murrell (2004) but as a junior synonym of $D$. niveus Neumann, 1897 in Camicas et al. (1998). Filippova (1997) regards D. ushakovae as valid, but one of us (AEP) thinks it probable that this species is a junior synonym of D. marginatus (Sulzer, 1776). We provisionally accept $D$. ushakovae until type comparisons clarify the situation.

Haemaphysalis anomaloceraea Teng, 1984 is treated as a valid species in Horak et al. (2002) and in Barker and Murrell (2004) but is listed as a synonym of H. shimoga Trapido and Hoogstraal, 1964 in Camicas et al. (1998). However, Keirans and Robbins (1999) support the validity of this species, and we agree because we have been unable to find any grounds for synonymization.

Haemaphysalis filippovae Bolotin, 1979 is listed as a valid species in Horak et al. (2002) and in Barker and Murrell (2004) but is considered a synonym of H. concinna Koch, 1844 in Camicas et al. (1998), who regard H. filippovae as a "forme anormale". Filippova (1997) redescribed both taxa, and Keirans and Robbins (1999) do not question the validity of this species. Accordingly, we consider $H$. filippovae a good name.

Haemaphysalis pavlovskyi Pospelova-Shtrom, 1935, is listed as a valid species in Horak et al. (2002) and in Barker and Murrell (2004) but is considered a junior synonym of $H$. doenitzi Warburton and Nuttall, 1909 by Camicas et al. (1998). However, the redescription of $H$. doenitzi by Hoogstraal and Wassef (1973) and that of H. pavlovskyi by Filippova (1997), which includes drawings of the holotype, argue for the validity of both species.

Hyalomma excavatum Koch, 1844, is recognized as a subspecies of $H$. anatolicum by Camicas et al. (1998) and Horak et al. (2002) but is not included in Barker and Murrell (2004). This species was validated and reinstated by Apanaskevich and Horak (2005). 
Hyalomma isaaci Sharif, 1928, recognized as a subspecies of $H$. marginatum by Camicas et al. (1998) and Horak et al. (2002) but ignored in Barker and Murrell (2004), was validated and reinstated as a full species by Apanaskevich and Horak (2008).

Hyalomma rufipes Koch, 1844, is considered a valid species by Barker and Murrell (2004) but a subspecies of $H$. marginatum Koch, 1844 by Camicas et al. (1998) and by Horak et al. (2002). Recently, Apanaskevich and Horak (2008) soundly validated this species.

Hyalomma turanicum Pomerantzev, 1946, is included in Horak et al. (2002) and in Barker and Murrell (2004) but not in Camicas et al. (1998), where it is listed as a subspecies of $H$. marginatum. Recently, Apanaskevich and Horak (2008) presented convincing evidence of this species' validity.

Ixodes arabukiensis Arthur, 1959 and I. djaronensis Neumann, 1907 are both considered valid in Horak et al. (2002) and Barker and Murrell (2004), but Camicas et al. (1998) list arabukiensis as a synonym of djaronensis. Females of both species differ in hypostomal dentition, but no type comparison has been conducted. We tentatively regard I. arabukiensis as a valid species.

Ixodes boliviensis Neumann, 1904 is treated as a junior synonym of $I$. diversifossus Neumann, 1899 by Camicas et al. (1998) but is listed as valid by Horak et al. (2002) and Barker and Murrell (2004). Keirans and Clifford (1978) commented on the similarity of these species, noting that $I$. diversifossus differs only in its possession of large lateral carinae. We provisionally maintain the validity of $I$. boliviensis, pending a comparison of types.

Ixodes columnae Takada and Fujita, 1992 is not mentioned in Camicas et al. (1998) but is listed in Horak et al. (2002) and in Barker and Murrell (2004). The taxonomic validity of this species is certain.

Ixodes maslovi Emel'yanova and Kozlovskaya, 1967 is listed as a valid species in Horak et al. (2002) and in Barker and Murrell (2004) but is relegated to the synonymy of I. persulcatus Schulze, 1930 in Camicas et al. (1998). Filippova (1977) redescribed both species, and because we have found no sound information supporting the position of Camicas et al. (1998), we provisionally consider I. maslovi a valid taxon.

Ixodes sachalinensis Filippova, 1971 is also listed as a junior synonym of I. persulcatus Schulze, 1930 in Camicas et al. (1998) but is accorded species status in Horak et al. (2002) and Barker and Murrell (2004). Again, we have found no sound information affirming the classification of Camicas et al. (1998), and therefore we provisionally consider $I$. sachalinensis to be a valid species.

Ixodes siamensis Kitaoka and Suzuki, 1983 is treated as a junior synonym of I. ovatus Neumann, 1899 in Camicas et al. (1998) but as a valid species in Horak et al. (2002) and Barker and Murrell (2004). Petney and Keirans (1994) doubt the validity of this species, while Keirans and Robbins (1999) list it as valid. We tentatively agree with the last-named authors, but a revision of the I. ovatus group, as proposed by Hoogstraal et al. (1973), is clearly in order.

Ixodes sigelos Keirans, Clifford and Corwin, 1976 is listed as a junior synonym of $I$. abrocomae Lahille, 1916 by Camicas et al. (1998) but is accepted as valid by Horak et al. 
(2002) and Barker and Murrell (2004). Lahille (1916) described the male (other stages unknown) of I. abrocomae, and Keirans et al. (1976) described the female, nymph and larva of I. sigelos (male unknown). To our knowledge, no further descriptions of these tick species have been published. Therefore, the synonymy of Camicas et al. (1998) appears to be unjustified and we consider I. sigelos valid.

Ixodes succineus Weidner, 1964 is a fossil species close to I. ricinus (Linnaeus, 1758) that is listed by Camicas et al. (1998) but is ignored by Horak et al. (2002) and by Barker and Murrell (2004), although the latter authors include names for other fossil tick taxa. We find no reason to consider this name invalid.

Rhipicephalus aurantiacus Neumann, 1907 is considered a valid name in Camicas et al. (1998) but not in Horak et al. (2002) or Barker and Murrell (2004). Walker et al. (2000) consider this name a junior synonym of R. ziemanni Neumann, 1904, but in their discussion of the latter species the situation is less clear because the types were not examined and the authors state that further studies are needed. We therefore provisionally regard $R$. aurantiacus as valid until types can be compared.

Rhipicephalus cliffordi Morel, 1965 is considered a valid name in Camicas et al. (1998) but not in Horak et al. (2002) or Barker and Murrell (2004). Walker et al. (2000) reduced this name to a junior synonym of $R$. pseudolongus Santos Dias, 1953. Once again, however, the types of these and related species were not compared. We therefore consider $R$. cliffordi to be a valid name, pending type comparisons.

Rhipicephalus pilans Schulze, 1935 is considered a subspecies of $R$. haemaphysaloides Supino, 1897 in Camicas et al. (1998) but is listed as a full species in Horak et al. (2002) and Barker and Murrell (2004). Walker et al. (2000) clearly delineated the differences between $R$. pilans and $R$. haemaphysaloides, and we agree with their assessment.

Rhipicephalus pseudolongus Santos Dias, 1953 is treated as a junior synonym of $R$. longus Neumann, 1907 in Camicas et al. (1998) but as a valid species in Horak et al. (2002) and Barker and Murrell (2004). Walker et al. (2000) clearly described the taxonomic history of this species and consider it provisionally valid until a type comparison can be made.

Rhipicephalus serranoi Santos Dias, 1950 is listed as a synonym of $R$. punctatus Warburton, 1912 by Camicas et al. (1998) but as a valid species by Horak et al. (2002) and Barker and Murrell (2004). Walker et al. (2000) treated R. serranoi as a valid species and described its morphological characteristics.

Rhipicephalus tetracornus Kitaoka and Suzuki, 1983 is considered valid in Camicas et al. (1998) but not in Horak et al. (2002) or Barker and Murrell (2004). All adults and some of the nymphs and larvae of this species were lost while being shipped for illustration; therefore, Walker et al. (2000) have elected to treat $R$. tetracornus as a species incertae sedis until new material becomes available. However, the description in Kitaoka and Suzuki (1983) is sound and a holotype nymph exists in the National Science Museum, Natural History Institute, Shinjuku, Tokyo. Since no claim has been made that $R$. tetracornus is a synonym of other Rhipicephalus species, we accept $R$. tetracornus as valid. 


\section{Spelling discrepancies in names of tick species}

Haemaphysalis quinghaiensis Teng, 1980 is spelled qinghaiensis by Horak et al. (2002) and Barker and Murrell (2004) and even in Teng's original description (Teng 1980). Nonetheless, Latin grammar dictates that the correct spelling for this species is quinghaiensis, as recorded in Camicas et al. (1998).

Ixodes kaschmiricus Pomerantzev, 1948 is spelled I. kashimiricus in Horak et al. (2002) and Barker and Murrell (2004), but I. kaschmiricus in Pomerantzev (1948), Hoogstraal (1970), and Camicas et al. (1998). We have concluded that Pomerantzev's original (Pomerantzev 1948) spelling is correct.

Ixodes pomeranzevi Serdyukova, 1941 is spelled I. pomerantzevi by several authors, including Clifford et al. (1973), and Robbins and Keirans (1992), but the correct spelling for this species is I. pomeranzevi, as published by Serdyukova (1941), Camicas et al. (1998) [under the genus Pholeoixodes], Horak et al. (2002), and Barker and Murrell (2004).

Ixodes paranaensis Barros-Battesti, Arzua, Pichorim and Keirans, 2003 is spelled $I$. paranensis in Barker and Murrell (2004).

See also Amblyomma curruca and Amblyomma trinitatis in the list of invalid tick names.

\section{Names for new or resurrected species (2003- 2008)}

Antricola delacruzi Estrada-Peña, Barros-Battesti and Venzal, 2004.

Antricola guglielmonei Estrada-Peña, Barros-Battesti and Venzal, 2004.

Antricola inexpectata Estrada-Peña, Barros-Battesti and Venzal, 2004.

Argas keiransi Estrada-Peña, Venzal and González-Acuña, 2003.

Carios rondoniensis Labruna et al. 2008. The morphological and molecular relationships of this species to the type taxon of the genus, Carios vespertilionis Latreille, 1796, are ambiguous. Other authors likely will classify this species in the genera Alectorobius or Ornithodoros.

Ornithodoros rioplatensis Venzal, Estrada-Peña and Mangold, 2008. As in the case of Carios rondoniensis, this new species may be considered by different workers to belong to Alectorobius or Carios.

Amblyomma latepunctatum Tonelli-Rondelli, 1939. A species that was long confused with A. incisum Neumann, 1906 and A. scalpturatum Neumann, 1906 but that was compellingly resurrected by Labruna et al. (2005). 
Amblyomma romitii Tonelli-Rondelli, 1939. This species had been considered a junior synonym of A. extraoculatum Neumann, 1899 but was definitively resurrected by BarrosBattesti et al. (2007).

Bothriocroton tachyglossi (Roberts, 1953). See Bothriocroton tachyglossi in "Controversial tick names considered valid".

Haemaphysalis colesbergensis Apanaskevich and Horak, 2008.

Haemaphysalis knobigera Prakasan and Ramani 2007. The original description and illustrations of this species are very poor; moreover, given the long history of Haemaphysalis studies in India (Trapido et al. 1964; Hoogstraal and Kim 1985), it seems unlikely that a new member of this genus would be found on domestic stock (cows and goats). Therefore, while we are listing this name for the sake of completeness, we strongly doubt its validity.

Haemaphysalis oliveri Apanaskevich and Horak, 2008.

Hyalomma glabrum Delpy, 1949. Apanaskevich and Horak (2006) demonstrated that the African populations of Hyalomma turanicum correspond to the resurrected species $H$. glabrum.

Hyalomma isaaci Sharif, 1928. See Hyalomma isaaci in "Controversial tick names considered valid."

Ixodes dicei Keirans and Ajohda, 2003.

Ixodes paranaensis Barros-Battesti, Arzua, Pichorim and Keirans, 2003.

Nosomma keralensis Prakasan and Ramani 2007. The original description and illustrations of this supposedly second species of Nosomma are very poor; moreover, it seems unlikely that a new member of this striking and otherwise monotypic genus would be found on domestic stock (buffalo), and the character states used to differentiate this taxon from $N$. monstrosum (Nuttall and Warburton 1908) - the extent of ornamentation and the degree of punctationare highly variable. Therefore, while we are listing this name for the sake of inclusiveness, we strongly doubt its validity.

Acknowledgments We thank Prof. F. Jongejan, the Coordinator of the Integrated Consortium on Ticks and Tick-borne Diseases 3, for his encouragement, and Prof. R. Meléndez for his search of the type of A. beaurepairei. We are grateful to M. Sánchez for her assistance in searching the literature. Thanks also to the Instituto Nacional de Tecnología Agropecuaria, Asociación Cooperadora de la Estación Experimental Agropecuaria Rafaela del Instituto Nacional de Tecnología Agropecuaria and to the Consejo Nacional de Investigaciones Científicas y Técnicas, Argentina, for supporting the research of AAG. 


\section{References}

Amorim M, Gazeta GS, Bossi DEP, Linhares AX (2003) Carrapatos Ixodes (Haemixodes) serrafreirei sp. n. em roedores silvestres dos estados do Rio de Janeiro e de Sao Paulo. Entomol Vectores 10:407-410

Andrews RH, Beveridge I, Bull CM, Chilton MB, Dixon B, Petney T (2006) Systematic status of Aponomma tachyglossi Roberts (Acari: Ixodidae) from echidnas, Tachyglossus aculeatus, from Queensland, Australia. Syst Appl Acarol 11:23-39

Apanaskevich DA, Horak IG (2005) The genus Hyalomma Koch, 1844. II. Taxonomic status of $H$. (Euhyalomma) anatolicum Koch, 1844, H. (E.) excavatum Koch, 1844 (Acari, Ixodidae) with redescriptions of all stages. Acarina 13:181-197

Apanaskevich DA, Horak IG (2006) The genus Hyalomma Koch, 1844. I. Reinstatement of Hyalomma (Euhyalomma) glabrum Delpy, 1949 (Acari: Ixodidae) as a valid species with redescription of the adults, the first description of its immature stages and notes on its biology. Onderstepoort J Vet Res 73:1-12

Apanaskevich DA, Horak IG (2008) The genus Hyalomma Koch, 1844: V. Re-evaluation of the taxonomic rank of taxa comprising the $H$. (Euhyalomma) marginatum Koch complex of species (Acari: Ixodidae) with redescription of all parasitic stages and notes on biology. Int J Acarol 34:13-42

Aragão HB, da Fonseca F (1961a) Nota de ixodologia. VIII. Lista e chave para os representantes da fauna ixodológica brasileira. Mem Inst Oswaldo Cruz 59:115-129

Aragão HB, da Fonseca F (1961b) Nota de ixodologia. 9. O complexo ovale do género Amblyomma. Mem Inst Oswaldo Cruz 59:131-148

Arthur DR (1965) Ticks of the genus Ixodes in Africa. The Athlone Press, London

Barker SC, Murrell A (2002) Phylogeny, evolution and historical zoogeography of ticks: a review of recent progress. Exp Appl Acarol 28:55-68.

Barker SC, Murrell A (2004) Systematics and evolution of ticks with a list of valid genus and species names. Parasitology 129:S15-S36.

Barros-Battesti DM, Arzua M, Pichorim M, Keirans JE (2003) Ixodes (Multidentatus) paranaensis $\mathrm{n}$. sp. (Acari: Ixodidae) a parasite of Streptoprocne biscutata (Sclater 1865) (Apodiformes: Apodidae) birds in Brazil. Mem Inst Oswaldo Cruz 98:93-102

Barros-Battesti DM, Onofrio VC, Labruna MB, Martins JR, Guglielmone AA (2005) Redescription of Amblyomma fuscum Neumann, 1907 (Acari: Ixodidae), a rare South American tick confirmed in Brazil. Syst Parasitol 61:85-92.

Barros-Battesti DM, Arzua M, Onofrio VC, Labruna MB (2007) Validation and redescription of Amblyomma romitii Tonelli-Rondelli, 1939 (Acari: Ixodidae). Syst Parasitol 68:79-86.

Beati L, Keirans JE, Durden LA, Opiang MD (2008) Bothriocroton oudemansi Neumann, $1910 \mathrm{n}$. comb Acari: Ixodida: Ixodidae, an ectoparasite of the western long-beaked echidna in Papua New Guinea: redescription of the male and first description of the female and nymph. Syst Parasitol 69:185-200. 
Black WC, Piesman J (1994) Phylogeny of hard- and soft-ticks taxa (Acari: Ixodida) based on mitochondrial 16S rDNA sequences. Proc Natl Acad Sci USA 91:10034-10038.

Butler JF, Gibbs EPJ (1984) Distribution of potential soft tick vectors of African swine fever in the Caribbean region (Acari: Argasidae). Prev Vet Med 2:63-70.

Camicas JL, Hervy JP, Adam F, Morel PC (1998) Les tiques du monde. Nomenclature, stades décrits, hôtes, répartition (Acarida, Ixodida). Orstom, Paris

Clifford CM, Sonenshine DE, Keirans JE, Kohls GM (1973) Systematics of the subfamily Ixodinae (Acarina: Ixodidae). 1. The subgenera of Ixodes. Ann Entomol Soc Am 66:489-500

Dumbleton LJ (1953) The ticks (Ixodoidea) of the New Zealand Sub-region. Cape Expedition Ser Bull Dept Scient Ind Res, Wellington, New Zeal (14) 28 pp

Dumbleton LJ (1961) The ticks (Acarina: Ixodoidea) of sea birds in New Zealand waters. N Z J Sci 4:760-769

Estrada-Peña A, Castellá J (1994) Check-list of species of ticks (Ixodoidea). Part II. Genera Amblyomma, Anomalohimalya, Aponomma, Boophilus, Hyalomma, Maragaropus, Palpoboophilus, Rhipicentor and Uroboophilus. Doc Trav Inst R Sci Nat Belg (76) 117 pp

Estrada-Peña A, Venzal JM, Guglielmone AA (2002) Amblyomma dubitatum Neumann: description of nymph and redescription of adults, together with the description of the immature stages of $A$. triste Koch. Acarologia 42:323-333

Fairchild GB, Kohls GM, Tipton VJ (1966) The ticks of Panama (Acarina: Ixodoidea). In: Wenzel RL VJ, Tipton VJ (eds) Ectoparasites of Panama. Field Mus Nat Hist, Chicago, pp 167-219

Filippova NA (1964) Data on ticks of the subfamily Argasinae (Ixodoidea, Argasidae). Report II. Taxonomy of Palearctic Argasinae and diagnoses of the species of the USSR fauna for all active phases in the life cycle. Parazitol Sborn 22:7-27

Filippova NA (1966) Argasid ticks (Argasidae). Fauna SSSR 4 (3), 255 pp

Filippova NA (1977) Ixodid ticks of the subfamily Ixodinae. Fauna SSSR New Ser 4 (4) 396 pp

Filippova NA (1994) Classification of the subfamily Amblyomminae (Ixodidae) in connection with a reinvestigation of the chaetotaxy of the anal valves. Parazitologiya 28:3-12

Filippova NA (1997) Ixodid ticks of subfamily Amblyomminae. Arachnoidea 5:1-436

Filippova NA (2003) Prototypes of Hyalomma scupense Schulze, 1918 and H. detritum Schulze, 1919 (Acari: Ixodidae) in connection with microevolution within the genus. Parazitologiya 37:455-461

Gervais P (1844) Acarides. In: Histoire naturelle des insects (C.A. Walckenaer). Libraire Encyclopédique de Roret, Paris, pp 132-288 
Guglielmone AA, Keirans JE (2002) Ornithodoros kohlsi Guglielmone and Keirans (Acari: Ixodida: Argasidae), a new name for Ornithodoros boliviensis Kohls and Clifford, 1964. Proc Entomol Soc Wash 104:822

Guglielmone AA, Luciani CA, Mangold AJ (2001) Aspects of the ecology of Amblyomma argentinae Neumann, 1904 [= Amblyomma testudinis (Conil, 1877)] (Acari: Ixodidae). Syst Appl Acarol Spec Publ 8:1-12

Guglielmone AA, Estrada-Peña A, Keirans JE, Robbins RG (2003) Ticks (Acari: Ixodida) of the Neotropical zoogeographic region. Spec. Publ. Int. Cons. Ticks Tick-Borne Dis. Atalanta, Houten, The Netherlands

Hoogstraal H (1956) African Ixodoidea. I. Ticks of the Sudan (with special reference to Equatoria Province and with preliminary reviews of the genera Boophilus, Margaropus and Hyalomma). Dept. Navy Bur. Med. Surg., Washington DC, USA, 1101 pp

Hoogstraal $\mathrm{H}$ (1958) Bat ticks of the genus Argas (Ixodoidea, Argasidae). 3. The subgenus Carios, a redescription of $A$. (C.) vespertilionis (Latreille, 1802) and variation within an Egyptian population. Ann Entomol Soc Am 51:11-26

Hoogstraal H (1970) Human infestation by ticks (Ixodidae) in the Himalaya. In: Sing KS, Tandan BK (eds) H.D. Srivastana commemoration volume. Indian Vet Res Inst, Izatnagar, pp 75-89

Hoogstraal H (1985) Argasid and nuttalliellid ticks as parasites and vectors. Adv Parasitol 24:135238.

Hoogstraal H, Aeschlimann A (1982) Tick-host specificity. Bull Soc Entomol Suisse 55:5-32

Hoogstraal H, Kim KC (1985) Tick and mammal coevolution, with emphasis on Haemaphysalis. In: Kim KC (ed) Coevolution of parasitic arthropods and mammals. Wiley, New York, pp 505-568

Hoogstraal H, Wassef HY (1973) The Haemaphysalis ticks (Ixodoidea: Ixodidae) of birds. 3. H. (Ornithophysalis) subgen. n.: definition, species, hosts, and distribution in the Oriental, Palearctic, Malagasy, and Ethiopian faunal regions. J Parasitol 59:1099-1117.

Hoogstraal H, Clifford CM, Saito Y, Keirans JE (1973) Ixodes (Partipalpiger) ovatus Neumann, subgen. nov.:identity, hosts, ecology, and distribution (Ixodoidea: Ixodidae). J Med Entomol 10:157164

Horak IG, Camicas JL, Keirans JE (2002) The Argasidae, Ixodidae and Nuttalliellidae (Acari: Ixodida): a world list of valid tick names. Exp Appl Acarol 28:27-54.

Jones EK, Clifford CM (1972) The systematics of the subfamily Ornithodorinae (Acarina: Argasidae). V. A revised key to larval Argasidae of the Western Hemisphere and description of seven new species of Ornithodoros. Ann Entomol Soc Am 65:730-740

Jones EK, Clifford CM, Keirans JE, Kohls GM (1972) The ticks of Venezuela (Acarina: Ixodoidea) with a key to the species of Amblyomma in the Western Hemisphere. Brigham Young Univ Sci Bull Biol Ser 17:1-40

Kaiser MN, Hoogstraal H, Kohls GM (1964) The subgenus Persicargas, new subgenus (Ixodoidea, Argasidae, Argas). 1. A. (P.) arboreus, new species, an Egyptian persicus-like parasite of wild birds, with a redefinition of the subgenus Argas. Ann Entomol Soc Am 57:60-69 
Kaufman TS (1972) A revision of the genus Aponomma Neumann, 1899 (Acarina: Ixodidae). Ph.D. dissertation, University of Maryland, College Park

Keirans JE (1992) Systematics of the Ixodida (Argasidae, Ixodidae, Nuttalliellidae): an overview and some problems. In: Fivaz B, Petney T, Horak I (eds) Tick vector biology, medical and veterinary aspects. Springer, Berlin, pp 1-21

Keirans JE, Brewster BE (1981) The Nuttall and British Museum (Natural History) tick collections: lectotype designations for ticks (Acarina: Ixodoidea) described by Nuttall, Warburton, Cooper and Robinson. Bull Br Mus Nat Hist 41:153-178

Keirans JE, Clifford CM (1978) The genus Ixodes in the United States: a scanning electron microscope study and key to adults. J Med Entomol (Suppl 2) 149 pp

Keirans JE, Hillyard PD (2001) A catalogue of the type specimens of Ixodida (Acari: Argasidae, Ixodidae) deposited in the Natural History Museum, London. Occ Pap Syst Entomol (13), 74 pp

Keirans JE, Klompen JSH (1996) Amblyomma quadricavum (Schulze) (new combination), and Amblyomma arianae Keirans and Garris, a new junior synonym of Amblyomma quadricavum (Acari: Ixodidae). Proc Entomol Soc Wash 98:164-165

Keirans JE, Robbins RG (1999) A world checklist of genera, subgenera, and species of ticks (Acari: Ixodida) published from 1973-1997. J Vector Ecol 24:115-129

Keirans JE, Clifford CM, Corwin D (1976) Ixodes sigelos, n. sp. (Acarina: Ixodidae), a parasite of rodents in Chile, with a method for preparing ticks for examination by scanning electron microscopy. Acarologia 18:217-225

Kitaoka S, Suzuki H (1983) Studies on the parasite fauna of Thailand. 5. Parasitic ticks on mammals and description of Ixodes siamensis sp. n. and Rhipicephalus tetracornus sp. n. (Acarina: Ixodidae). Trop Med 25:205-219

Klompen JSH, Oliver JH (1993) Systematic relationships in the soft ticks (Acari: Ixodida: Argasidae). Syst Entomol 18:313-331.

Klompen JSH, Keirans JE, Durden LA (1995) Three new species of ticks (Ixodida: Argasidae: Carios) from fruit bats (Chiroptera: Pteropodidae) in the Australasian region, with notes on host associations. Acarologia 36:25-40

Klompen H, Dobson SJ, Barker SC (2002) A new subfamily, Bothriocrotoninae n. subfam., for the genus Bothriocroton Keirans, King and Sharrad, 1994 status amend. (Ixodida: Ixodidae), and the synonymy of Aponomma Neumann, 1899 with Amblyomma Koch, 1844. Syst Parasitol 53:101-107.

Kolonin GV (1995) Review of the ixodid tick fauna (Acari: Ixodidae) of Vietnam. J Med Entomol $32: 276-282$

Kolonin GV (2003) New data on ixodid tick fauna of Vietnam. Entomol Rev (Engl Transl) 83(Suppl 2):S190-S192 
Labruna MB, Keirans JE, Camargo LMA, Ribeiro AF, Soares RM, Camargo EP (2005) Amblyomma latepunctatum, a valid tick species (Acari: Ixodidae) long misidentified with both Amblyomma incisum and Amblyomma scalpturatum. J Parasitol 91:527-541.

Labruna MB, Terassini FA, Camargo LMA, Brandão PE, Ribeiro AF, Estrada-Peña A (2008) New reports of Antricola guglielmonei and Antricola delacruzi in Brazil, and a description of a new argasid species (Acari). J Parasitol 94:788-792.

Lahille F (1916) Descripción de un nuevo ixódido chileno. Rev Chil Hist Nat 20:107-108

Nava S, Szabó MPJ, Mangold AJ, Guglielmone AA (2008) Distribution, hosts, 16S rDNA sequences and phylogenetic position of the Neotropical tick Amblyomma parvum (Acari: Ixodidae). Ann Trop Med Parasitol 102:409-425.

Nava S, Guglielmone AA, Mangold AJ (2009) An overview of the systematics and evolution of ticks. Front Biosci 14:2857-2877 (published in 2008)

Neumann LG (1899) Révision de la famille des ixodidés ( $2^{\mathrm{e}}$ mémoire). Mem Soc Zool Fr 12:107-294

Norris DE, Klompen JSH, Keirans JE, Lane RS, Piesman J, Black WC (1997) Taxonomic status of Ixodes neotomae and I. spinipalpis (Acari: Ixodidae) based on mitochondrial DNA evidence. J Med Entomol 34:696-703

Olenev NO (1941) The geographical distribution and certain features of the ecology of the ticks Ixodes under the condition of the North-west of the USSR. 3 Soveshch Parazit Probl: 39-40

Packard AS (1869) List of hymenopterous and lepidopterous insects collected by the Smithsonian Expedition to South America, under Prof. James Orten; appendix to report on Articulates. Annu Rep Peabody Acad Sci: 56-69

Petney TN, Keirans JE (1994) Ticks of the genus Ixodes in South-east Asia. Trop Biomed 11:123134

Petney TN, Keirans JE (1996) Ticks of the genus Aponomma in South-east Asia. Trop Biomed 13:167-172

Pomerantzev BI (1948) New ticks belonging to the family Ixodidae. Acad Sci USSR Zool Inst Parasitol Symp 10:20-24

Pospelova-Shtrom MV (1969) On the Argasidae system (with description of two new subfamilies, three new tribes and one new genus). Med Parasitol Parazitarn Bol 15:47-58

Prakasan K, Ramani N (2007) Two new species of ixodid ticks (Acarina: Ixodida) from Kerala, India. Int J Zool Res 3:169-177

Robbins RG, Keirans JE (1992) Systematics and ecology of the subgenus Ixodiopsis (Acari: Ixodidae: Ixodes). Entomol Soc Am. Thomas Say Found Monogr 14:1-159

Robbins RG, Robbins EM (2003) An indexed, annotated bibliography of the Chinese- and Japaneselanguage papers on ticks and tick-borne diseases translated under the editorship of the late Harry Hoogstraal (1917-1986). Syst Appl Acarol Spec Publ 17:1-12 
Roberts FHS (1960) A systematic study of the Australian species of the genus Ixodes (Acarina: Ixodidae). Aust J Zool 8:392-485.

Roberts FHS (1970) Australian ticks. CSIRO, Melbourne

Robinson LE (1926) Ticks, A monograph of the Ixodoidea. Part IV. The genus Amblyomma. Cambridge University Press, London

Santos Dias JAT (1956) Invalidação de algumas espécies ixodológicas originalmente determinadas em resultado de indevida rotulagem de material. Inst Med Trop 13:199-208

Santos Dias JAT (1958) Notes on various ticks (Acarina-Ixodidae) in collection at some entomological institutes in Paris and London. Inst Med Trop 15:459-563

Santos Dias JAT (1961) Reabilitação de duas espécies neotrópicas do género Amblyomma Koch, 1844. An Serv Vet Moçambique (1955-1959) (7):237-243

Schulze P (1933) Die Arten der Zeckengattung Dermacentor s. Z Parasitenkd 6:416-431.

Schulze P (1935) Zur Zeckenfauna Formosas. Zool Anz 112:233-237

Scudder SH (1885) Fossilen Myriopoden, Arachnoideen und Insekten. In Zittel KA Handbuch der Palaeontologie I. Abteilung, Paleozoologie. Bd. II, Druck und Verlag von R. Oldenbourg, München und Leipzig, pp 721-831

Scudder SH (1890) The Tertiary insects of North America. United States Geological Survey of Territories. Government Printing Office, Washington

Serdyukova GV (1941) A relict tick form I. pomeranzevi sp. n. Comp Rend Acad Sci USSR 32:519_ 522

Teng KF (1963) A new species of the genus Dermacentor (Ixodidae). Acta Entomol Sin 12:225-228 (In English: Translation 446 US Naval Medical Research Unit No. 3, Cairo, Egypt)

Teng KF (1980) Two new species of Haemaphysalis from China (Acarina: Ixodidae). Acta Zootax Sin 5:144-149

Teng KF (1986) Studies on the genus Ixodes in China (Acari: Ixodidae). Acta Zootax Sin 11:46-53

Trapido H, Varma MGR, Rajagopalan PK, Singh KRP, Rebello MJ (1964) A guide to the identification of all stages of the Haemaphysalis ticks of South India. Bull Entomol Res 55:249-270

Venzal JM, Castro O, Cabrera P, de Souza C, Fregueiro G, Barros-Battesti DM, Keirans JE (2001) Ixodes (Haemixodes) longiscutatum Boero (new status) and $I$. $(H$.) uruguayensis Kohls and Clifford, a new synonym of $I$. (H.) longiscutatum (Acari: Ixodidae). Mem Inst Oswaldo Cruz 96:1121-1122.

Venzal JM, Estrada-Peña A, Mangold AJ, González-Acuña D, Guglielmone AA (2008a) The Ornithodoros (Alectorobius) talaje species group (Acari: Ixodida: Argasidae): description of Ornithodoros (Alectorobius) rioplatensis n. sp. from southern South America. J Med Entomol 45:832840. 
Venzal JM, Nava S, Beldoménico PM, Barros-Battesti DM, Estrada-Peña A, Guglielmone AA (2008b) Hosts and distribution of Ixodes longiscutatus Boero, 1944 (Acari: Ixodidae). Syst Appl Acarol 13:102-108

Vogelsang EG, Santos Dias JA (1953) Contribución al estudio de la fauna ixodológica en Venezuela. Rev Med Vet Parasitol 12:3-62

Voltzit OV, Keirans JE (2002) A review of Asian Amblyomma species (Acari, Ixodida, Ixodidae). Acarina 10:95-136

Voltzit OV, Keirans JE (2003) A review of African Amblyomma species (Acari, Ixodida, Ixodidae). Acarina 11:135-214

Walker JB, Olwage A (1987) The tick vectors of Cowdria ruminantium (Ixodoidea; Ixodidae, genus Amblyomma) and their distribution. Onderstepoort J Vet Res 54:353-379

Walker JB, Keirans JE, Horak IG (2000) The genus Rhipicephalus (Acari, Ixodidae). A guide to the brown ticks of the world, Cambridge University Press, Cambridge

Weidner H (1964) Eine Zecke, Ixodes succineus sp. n. im baltischen Bernstein. Veroff Uberseemus Bremen Ser A 3:143-151

Wilson N (1970) Acarina: Metastigmata: Ixodidae of South Georgia, Heard and Kerguelen. Pac Insects Monogr 23:78-88 